IJ§ER

ISSN: 2149-5939
International Journal of Social Sciences and Education Research

Online, http://dergipark.gov.tr/ijsser

Volume: 3(5), 2017

\title{
Globalization and International Trade
}

\author{
Gözde Yirmibeşoğlu ${ }^{1}$
}

Received Date: 19/09/2017

Accepted Date: 25 / $10 / 2017$

\begin{abstract}
Globalization has been a significant debate issue in the academic research for the last decades. There is not a consensus on the initiation of globalization. Although there are many aspects of globalization such as economic, social, political and cultural features, this paper focuses mostly on its economic aspect. Globalization broke down commercial borders between countries and destroyed barriers against trade among countries. As a result, business performing in the international arena were forced to change their strategies. Thus, international trade gained a variety of new dimensions. Hence, the aim of this paper is to explore the impact of globalization on world trade by investigating the development of globalization with regards to consumption culture and media imperialism.
\end{abstract}

Keywords: Globalization, International Trade, Consumer Culture, Culture Imperialism, Media Imperialism

\section{Introduction}

In the last decades, globalization has been a prevalent term used quite frequently in a large variety of fields of academic arena. Although it is used popularly in academic sphere, it does not have one single explanation or definition. Connotation of globalization is embedded in terms such as internationalization, liberalization, Westernization and modernization. It refers to cover and embrace the whole world. Recently, it has been pointing at an implication to the developments in the fields such as communication, information, cross-border capital flow, environmental problems and disasters, standard production, cultural standardization and homogenous society. There is a significant connection between globalization and economy, politics, culture and society. Globalization wipes out national cultures in order to create one single standardized culture so as to give rise to international trade and global capital. It stresses a unique culture created by means of mass communication devices in order to create consumer societies. In fact, societies consuming the brands of global capital do not have anything in common with the creator societies of such brands. However, they are made inclined towards a standard type of life by means of globalization.

Globalization refers to a movement leading to the integration of the national markets into the worldwide markets, specifically into economic, financial and communications arenas. It stresses free transfer of capital, goods and services by crossing the borders. The objective is dependency by means of an interconnected world. It suggests the investment of business beyond domestic borders. Although there is discussion about the start of the globalization, most agree that globalization meant an interconnected world in both economical an informational sense after the cold war. Later, after the second half of 1980's, the term globalization started to be expressed intensively in academic texts. Initial works on globalization underlined its economic dimension. For

\footnotetext{
${ }^{1}$ Assoc. Prof. Dr., Akdeniz University, Antalya, Turkey, gozdey@akdeniz.edu.tr 
Yirmibeşoğlu, G. (2017). Globalization and International Trade. International Journal of Social Sciences and Education Research, 3(5), 1787-1796.

instance, writers such as Robertson and Khondker touch upon its economic side and define globalization as the progressive spread of economic liberalization across the globe (1998: 28). However, the exploration of the term related to its informational dimension took place later.

Globalization perceives the whole world as a global village as it is stated by McLuhan who declares that "as electrically contracted, the globe is no more than a village. Electric speed at bringing all social and political functions together in a sudden implosion has heightened human awareness of responsibility to an intense degree" (1964: 5). The result of such an electronically connected world is concentrated social links as stated by Anthony Giddens, who emphasized that "globalization can be defined as the intensification of social relations throughout the world, linking distant localities in such a way that local happenings are formed as a result of events that occur many miles away and vice versa" (1991: 64).

Fundamental character of globalization affecting economically the whole world is interconnection and interdependency among the nation states. The basis of the new phase of world economy is trade beyond the national borders. National economies have been exceedingly reliant on global economy. Decrease in the custom taxes and eradication of constraints on the movement of goods, capital and labor between nation states have resulted in the growth in international capital and investments. As a consequence, this paper aiming at investigating the link between globalization and global trade underlines initially the role of consumer culture, leading to the rise in capital growth and then the development of transnational companies. The methodology chosen in this article is literature review because the purpose of this paper is to discover the link between globalization and international trade by exploring the theoretical background on the issue and investigating its impact on free movement of goods, labor and capital. Since there is a large number of studies presenting the data related to the sharp rise in the world trade in the last decades, this paper focuses on the interpretation of the influence of globalization on trade beyond borders with regards to the impact of media.

\section{Globally connected world and rise of consumer culture}

Globalization has a large variety of aspects. It influences directly or indirectly the individual's life, and thus, the life of the society as a whole. Individuals are confined into a homogenous lifestyle, in which consumption plays the primary role. However, they have never been aware of the fact that they have been locked by the limits of globalization. There is a large number of discussions about the initiation of globalization and its meaning. Some thinkers such as Baldwin and Martin believe that there have been at least two episodes of globalization since the mid- $19^{\text {th }}$ century (1999: 10). They declare that the first phase starts in the 1850's and ended with the start of World War I. The second one starts following World War II and it still continues. They both mark that globalization means rapid trade and fast production. As globalization influences the whole world, its speed is sometimes fast and some other times stagnant or even worse.

Murshed believes that "a convenient date to mark the commencement of the present era of globalization could be roughly 1980, following China's adoption of open-door policies. China held nearly 5 per cent of world exports in 1980" (2002: 17). However, the rate rises to just about 15 by 1994 with the contribution of Asian tigers. Accordingly, the GNP of China and Asian tigers has increased almost three times more than the one of the OECD countries. When the possibilities changed in international and domestic spheres, foreign trade of China was affected since it was 
Yirmibeşoğlu, G. (2017). Globalization and International Trade. International Journal of Social Sciences and Education Research, 3(5), 1787-1796.

directly linked. Scientific and technological progress was performed due to economic globalization, and thus this was a significant motivation for cooperation between countries. This was important for the integration of China, whose government was giving the primary focus on reforms and opening up policy. As a consequence, it improved its economic and technological advance, wisely used foreign investment and unfortunately contributed to the deepening of the division of labor. The result was a rapid economic growth stemming mostly from the reforms and mutual benefit gained from globalization. Naturally, great motive behind this rapid economic growth was the consumer culture.

Consumption is as important as saving and investment in the world of economic activities. As the ultimate step of the economic action, goods and services presented to the individual's choice by means of consumption. Since the resources are transformed into such goods and services, they become the tools of economic action for the people who want to use them. Individuals are prepared to use them. Hence, the science interested in the rational behavior of individuals, economics, deals with their will to consume reasonably. Consumer culture is relatively new kind of culture, in which the meaning of the world swings between consumer goods and individual consumer by means of a number of instruments such as fashion and advertisement. As McCracken remarks, "consumer goods have a significance that goes beyond their utilitarian character and commercial value" (1986:71).

Keynes, famous economist in the 1930's, has significant contribution with his arguments on the relationship between consumption, saving and investment. He declares that men are disposed, as a rule and on average, to increase their consumption as their income increases, but not as much as their income increases (General Theory, 1936: 96). In his theory he is interested in the determination of aggregate effective demand and national income. In addition, he analyses individual consumption behavior. He argues that investment and saving are not equal as investment is a function of the expected rate of return as well as the interest rate. Rise in savings can reduce the interest rate and encourage increase in investment. However, if the projected rate of return is low, investment will not increase in proportion to saving. As a result, the level of demand will decrease. In his theory, susceptibility to consume is considerably vital. He argues that there is an equilibrium between aggregate demand and aggregate supply. Moreover, consumption is frequently reliant on income since people are eager to consume and have the capacity to consume when their income increases. He explains his concept of expenditure multiplier by stating that rise in investment causes rise in income. Hence, Keynes developed a theory of consumption that focused essentially on the importance of people's disposable income in determining their spending. A rise in real income gives people greater financial resources to spend or save.

Thus, starting with Keynes in the first decades of the twentieth century, consumption has been a key component of global economy. With the practice of neo-liberal theory and the increasing spread of global trade, the stress on consumption played a chief role in global economy. For instance, Ralf Dahrendorff, who affirms that globalization starts with the presence of humankind on moon, highlights clearly the change in capitalism by underlining the transformation from saving to spending and to borrowing (1995: 14). Household savings demonstrate the share of household income which is not consumed. It represents short and long-term economic activity. Changes in the savings generally serves to reduce economic instability in the short term. In other words, if the saving rate is higher consumption will diminish. In the long term, saving rate is the main constituent demonstrating the country's lending capacity, which means it has a major role in the way the economy functions. Furthermore, it helps to guess future level of growth. 
Yirmibeșoğlu, G. (2017). Globalization and International Trade. International Journal of Social Sciences and Education Research, 3(5), 1787-1796.

OECD countries show substantially different national saving rates and thus investment rates. However, the similar feature for all of the is that the savings and investments have been decreasing since the 1960's. For the OECD area as a whole, the average ratio of gross national saving to GNP fell by 3 percentage points between 1960-70 and 1981-88 (Dean, Durand, Fallon and Hoeller, 1987: 10). The rate of saving and investment exhibits preference concerning consumption and production. To illustrate, low saving rate reflects preference for consumption to some extent. In global economy, the recent matter of concern is insufficient national saving to support expected national investment. The level of national investment may not meet exactly the level of national saving in an open economy, which is the genuine characteristic of the global economic atmosphere since the introduction of neo-liberal policies after the 1980's and the spread of globalization. Therefore, domestic investment has been financed by foreign capital inflows. The decades before the spread of neo-liberal policies, particularly the 1950's and 1960's show totally a different picture due to neo-classical closed-economy model, in which the steady-state model was significantly appreciated. In that period, there were ample investment opportunities to undertake post-war reconstruction and achieve technological catch-up with the United States (Maddison, 1987). Today, the picture is totally different since global companies lead the economy of the world and the speed of international trade rises with the impact of consumer culture and multinational companies.

Consumer culture refers to a kind of material culture related to the market. Furthermore, it denotes a specific relationship between the individual consumer and the goods and services consumed. Different than its economic connotation, its social inference underlines the difference between consumer culture and consumption. Accordingly, consumer culture is not a process of the individual action realized by simply buying and using up. It mainly indicates certain values and status. The sociological prominence of consumer culture was discovered in the 1990's due to the focus of academic work with the impact of cultural aspect of post-modernity. A large number of scholars have been interested in this topic. To illustrate, Featherstone states that "the term, as it suggests, refers to the culture of the consumer society. It is based on the assumption that the movement towards mass consumption was accompanied by a general reorganization of symbolic production, everyday experiences and practices" (1990: 111). Besides, Slater expresses the bound between consumer culture and modernity (1997). Nava (1991:157) and Sassatelli (2007), on the other hand, emphasize the political aspect of consumption.

Consumer culture, a collection of relations based on cultural experiences of ordinary life and material resources. The role of the market economy is primary in the evolution of consumer culture. Moreover, regular daily life experience relies on such material means and tools. That is the reason why consumption rules behavior in this system of culture. In this system, current cultural values and norms are transmitted to the future generations. It is a modern system, in which free personal choice is promoted and individuals are free and rational. In fact, authority of tradition does not exist no longer. Thus, consumer culture denotes an economy in which value has been divorced from the material satisfaction of wants and the sign value of goods takes precedence (Baudrillard 1996/1968; 1998/1970).

In fact, there has been intense academic concern in consumption and consumer culture since the beginning of the twentieth century. Particularly, the philosophers of Frankfurt School focused on the issue of consumption in their critique of culture industry, which is the concept created and developed by the thinkers of the School. Initially, Veblen's research on the new leisure class 
Yirmibeşoğlu, G. (2017). Globalization and International Trade. International Journal of Social Sciences and Education Research, 3(5), 1787-1796.

formed by the rich American population concentrated on consumption at the end of nineteenth century (1899). Following Thorstein Veblen, Max Horkeimer and Theodor Adorno contributed significantly on the academic arena by underlining commercial marketing of culture. Both academicians formulated the term culture industry in their critical theory, which means a kind of industry dealing with the production of culture in contradiction of authentic culture (1979). Frankfurt School criticizes false need created by capitalism and colonization of everyday life by commodification. Their prominent contribution is their critique on ordinary understanding of consumption and consumer culture.

Both philosophers, Horkeimer and Adorno, claim that culture produced by industrial tools constitute barriers against imagination of individuals. According to them, culture industry offers its own goods and services and thus the only thing that the individual can do is to consume them. They condemn mass production because they state that homogenized goods are the products of mass production. They give the example of films and argue that all films have become similar in their basic form. They claim that targets of the culture industry are indeed economic, which is a similar case for any industry. In contrast to culture industry, authentic culture promotes and develops imagination of the individuals and stimulates independent thinking. In comparison with terms such as mass culture and mass production, authentic culture is exceptional and inimitable. In fact, both philosophers, Horkheimer and Adorno underline the issue of mass production, which is the chief component of globalization. They claim that companies search for profit maximization led to the expansion of culture industry.

To conclude, consumption can be evaluated in the context of culture industry, in which false needs such as lifestyle, fashion and taste are placed. In recent global economy, companies track down audiences enjoying life by means of consumer practices (Gabriel and Lang, 1995). Customers of global economy are limited by the barriers of consumer culture. The theoretical structure of consumer culture can be traced back in the academic contributions of the Frankfurt School thinkers. With the noticeable impact of improvements in global communication, spread of consumer culture has accelerated. Standard production and homogenized goods have become primary elements in the consumption approach of masses in global economy. Marshall McLuhan, the writer of The Gutenberg Galaxy and the inventor of the term global village asserts that "time has ceased and space has vanished" (. Today, global village of McLuhan refers to a market constituted by the Internet, where trade and commerce are accessed easily and at a low cost. All these developments in this century gave rise to the speed of global trade and to the traffic of standard product to be consumed rapidly.

\section{Role of the advance in communication and media in economic globalization}

International communication, a relatively recent academic area, deals with topics related to not only communication between nation states but also between international organizations or business. That is the reason why global hegemony, power and profit relations along with interdependency among the nation states and global business conglomerations take place in the interest areas of international communication. International communication is an inevitably important topic in the age of globalization due to inter-dependent and inter-connected rule of the new world, where international and cultural relations are primary components. In contrast to the experiences of the past decades, recent age of globalization goes beyond local power, used to be under pressure of foreign forces in the issues such as politics, trade, culture, safety and health. Within this perspective of pressure, international communication is a complex and critical power (Semati, 2004: 
Yirmibeşoğlu, G. (2017). Globalization and International Trade. International Journal of Social Sciences and Education Research, 3(5), 1787-1796.

1). The rule of international communication includes all kinds of bilateral relations between states and private sector of the business world as well as international organizations and states.

Studies focused on international communication were initiated in the U.S.A. after the World War I because the significant role played by media and communication and improved electronic system were discovered at that period. International relations are related to diplomatic relations and organizations as well as wars (Rantanen, 2004: 1-2). The origin of globalization of communication dates back to nineteenth century due to the impact of Industrial Revolution and the developments resulted in sharp rise in production and global trade. Nevertheless, global flow of communication occurred during the twentieth century as communication channels and spread of communication were perfectly realized at that period (Thompson, 1995: 159).

In fact, considerable role in relations between countries played by mass communication was realized after the 1980's. That is the reason why mass communication has been popular since then. One important influence of such a development is that persuasion mechanisms started to gain significance in addition to pressure mechanisms. Moreover, control of international companies on mass communication devices have increased. In fact, activities of international media can be summarized under four sections: communication technology and relations, institutionalization of communication technology, production and reproduction of communication technology and finally ideological support (Erdoğan, 1995: 65-66). Philosophy of global media is large diversity of product expansion and maximum profit (Girgin, 2002: 36).

Today, the meaning of globalization refers to trade in goods, services and assets as well as the Internet. Foreign competition has become chief activity of companies concentrating on internationally rising efficiency as national consumers have the ability to contact with a larger variety of goods and services with reduced costs. Globalization is perceived as a barrier against the development of national economies, which causes concerns such as cultural homogenization. Advances in communication technologies resulted in a rise in the speed of globalization and the term popularized by Jeremy Tunstall, cultural imperialism has become progressively prevalent. He indicates that "since the turn of the millennium, the cross-border trade of TV shows and films has grown (2013: 9). Thus, he relates cultural imperialism to this growth in global industry of movies and shows.

Subsequently, Oliver Boyd-Barret defined cultural imperialism as "the process whereby the ownership, structure, distribution of content of the media in any one country are singly or together subject to substantial external pressures from the media interests of any other country or countries without proportionate reciprocation of influence by the country so affected" (1977: 117). Ritzer went further and called this cultural homogenization McDolnaldization. He highlights that "it is possible to view a wide range of the most contemporary phenomena as being affected directly or indirectly by the McDonald's model and McDonaldization (2008:3). Hence, authentic, traditional and local culture has been wiped out by the media products of cultural imperialism dumping large amounts of films, shows and commercials on all over the globe. While explaining what Western culture imposes on other cultures, Tomlinson declares that "the media are generally located at the center of the cultural of the capitalist West, and there are several reasons for this, ranging from the pragmatic to the more theoretically principled" (1991: 39). 
Yirmibeşoğlu, G. (2017). Globalization and International Trade. International Journal of Social Sciences and Education Research, 3(5), 1787-1796.

The role of media on cultural imperialism in the age of globalization and a new world order is also studied by Sparks. Kaarle Nordenstreng discusses the contribution of Colin Sparks by announcing that "The concept of a New World Information and Communication Order, known as NWICO, became a leading theme in global media policy debates from the 1970s until the 1990s, covering the period from heights of decolonization to the collapse of Soviet communism" (2013: 348). Since the 1980s NWICO has been a debate issue in the academic discussions of the role played media in the world. It reflects arguments related to media concerning geopolitical competition between the West, originally American based policies, and the East, Soviet based policies in addition to the North, reflecting industrialized zone and the South reflecting the developing one. After the collapse of the Berlin Wall and the emergence of the globally interconned world order by means of global civil society, contemporary media studies flourished and gained importance in the understanding of the impact on neo-liberal policies, globalization and global world trade.

Colin Sparks, who focuses on cultural imperialism aspect of globalization, contributes to the convergence between globalization and cultural products. In his famous article, Media and Cultural Imperialism Reconsidered, he summarizes that "it is possible to advance a viable and coherent concept of cultural imperialism by investigating the ways in which state power and cultural power are intertwined in the production and circulation of cultural artefacts" (2012: 294). He envisages some of the recent struggles between states while enforcing their propaganda. In addition, he adds the new nature of journalism and content of news. Moreover, he discusses the control of the Internet and the influence of international media flow. Particularly, he touches upon the issue of protection of intellectual property by debating the role and nature of popular culture. $\mathrm{He}$ concludes that "imperialism, cultural imperialism, and the cultural consequences of imperialism are once again an essential part of the theoretical framework for the study of international communication" (2012: 296).

Before Sparks and Nordenstreng, in fact, Herman and Chomsky discussed propaganda model in the age of globalization in 1988 and they argued that "the mass media serve as a system for communicating messages and symbols to the general populace. It is their function to amuse, entertain, and inform, and to inculcate individuals with the values, beliefs, and codes of behavior that will integrate them into the institutional structures of the larger society. In a world of concentrated wealth and major conflicts of class interest, to fulfil this role requires systematic propaganda" (1988: 1). They both draw attention over the raw material of news passing through five filters that ultimately shape the news audiences. These filters govern what events are newsworthy, how they are covered, where they are placed within the media and how much coverage they receive. Herman and Chomsky concentrate on media behaviour rather than media effects while discussing propaganda model. They explain it by insisting on a profit-driven system of the corporate-owned news media serving the interests of established power. Mullen and Klaehn, on the other hand, criticize the contribution of Herman and Chomsky and declare that "although Herman and Chomsky have attended to the societal function of ideology and propaganda as an effective means of social control elsewhere in their work (Chomsky 1989; Herman, 1999), the PM is solely concerned with the questions of media performance and poses a direct challenge to the liberalpluralist view of how the media work" (2010: 217). As a result, in the globalized economy of the recent world order and constantly aggragating global power of the transnational corporates and finance institutions propaganda model has become a leading debate issue. 
Yirmibeșoğlu, G. (2017). Globalization and International Trade. International Journal of Social Sciences and Education Research, 3(5), 1787-1796.

In the perpetuation of a modern international system, domination is sustained by means of cultural imperialism stemming from the developled world towards the developing one. Media, used to perform particular and traditional activities of the past, has become lately the creator of culture itself. In this new perspective, media imperialism refers to performance among nation states. Furthermore, media technology, the structure of this technology, its ownership, production, diffusion and content play the primary roles. The relations between national systems and their effects along with their domination order are discussed in the area of media imperialism, in which dominating power exports its trade and political strategy.

Thus, global trade is susceptible to the power of media imperialism, which diffuses its political, economic and social domination towards unaware individuals. For instance, although some of the global media holdings are originally European, American media products are sustainable in the global market. That is the reason why such foreign holdings invest on American media business. The example is that many American film studios are bought by foreign companies, but this did not change the structure of Holywood movies. To illustrate, Rupert Murdoch, and Australian and American media owner, possesses most of the television channels in the United States. While debating on the new world order, cultural imperialism and its subsequent issue, media imperialism, replace the exploitation models of the past. Giant communication structures hold the power of the information ownership. As a result, such giant media holdings of the developed nations control the flow of information, which constitute the primary propaganda tools and devices.

\section{Conclusion}

Multi-national companies have had a major impact on the emergence of globalization. Globalization have had both positive and negative effects on world trade. It created a homogenous world, a global village, and it imposes individuals to become all similar and standard. In other words, it forces a cultural identity all over the world. Globalization is a new world order replacing the Cold War era. It is a process of integration, during which individuals, companies, nation states are joining together. This process cannot be stopped or restricted. It is inevitable. It forces the states to lift barriers against trade. In this new era, events stemming from any social, political and economic activity in any part of the world influences the individuals or corporations in another part. Globalization is governed by new technologies and new economic relations. Moreover, it is also a political sphere in which governments, international corporations, business, labor and civil society take place. Globalization includes international trade of goods and services, free circulation of capital and labor between countries and reproduction and practice of technology.

Accordingly, globalization requires the renewal of legal and institutional regulations so as to increase the power of competition. Basically, it is grounded on the ideal of global competition and free trade. In fact, since 1980, globalization has had a great impact on changes in technological developments and production styles. Technology, in particular, has had a major influence on the acceleration of globalization. Multi-national corporations transport their activities to a number of countries along with their organizational and administrative culture. Countries must be trustable and should not carry risks for its investments and production. Thus, globalization requires a competitive society. In this kind of society consumption is the major activity and consumption culture is imposed by international media. Particularly, media itself forces individuals to compete 
Yirmibeşoğlu, G. (2017). Globalization and International Trade. International Journal of Social Sciences and Education Research, 3(5), 1787-1796.

and consume. In that context, a consumption society is born. This new type of social network is dominated by culture imperialism and thus, media imperialism.

\section{References}

Adorno, T. and Horkheimer, M. (1979) Dialectic of Enlightenment. London, New Left Books, first published in 1944.

Baldwin, R.E. and Martin, P. (1999). "Two Vawes of Globalization: Superficial Similarities, Fundamental Differences”, NBER Working Papers, National Bureau of Economic Research 6904, p. 10.

Baudrillard, J. (1996). The System of Objects. London, Verso.

Baudrillard, J. (1998). The Consumer Society. London, Sage.

Boyd Barret, O. (1977). Media Imperialism. London, Sage.

Chomsky, Noam 1989. Necessary Illusions: Thought Control in Democratic Societies. London: Pluto

Dahrendorf, R. (1995). "Economic Opportunity, Civil Society and Political Liberty”, UNRISD Discussion Paper, 58, p. 14.

Dean, A., M. Durand, J. Fallon and P. Hoeller (1989). "Saving Trends and Behaviour in OECD Countries," OECD Economics and Statistics Department Working Papers, No. 67 (June), p. 10.

Erdoğan, İ. (1995). Dünyanın Çarpık Düzeni: Uluslararası İletişim. İstanbul, Kaynak. pp. 65-66.

Gabriel, Y. and Lang, T. (1995). The Unmanageable Consumer. London, Sage.

Featherstone, M. (ed.) (1990). Global Culture, Theory, Culture \& Society, special issue. Reprinted in 1990 as Global Culture: Nationalism, Globalization and Modernity. London, Sage.

Giddens, A. (1991). The Consequences of Modernity. Cambridge, Polity Press, p. 64.

Girgin, A. (2002). Uluslararası Iletişim: Haber Ajansları ve AA. İstanbul, Der, p. 36.

Herman, Edward S. 1999. The Myth of the Liberal Media: An Edward Herman Reader, New York: Peter Lang.

Herman, E. S. and Chomsky, N. (1988). Manufacturing Consent: The Political Economy of Mass Media. New York, Pantheon Books. p. 1.

Keynes, J.M. (1936). The General Theory of Employment, Interest, and Money. New York, Harcourt, Brace and Company. p. 36.

McCracken, G. (1986). "Culture and Consumption: A Theoretical Account of the Structure and Movement of the Cultural Meaning of Consumer Goods", Journal of Consumer Research (13), p. 71.

McLuhan, M. (1964). Understanding Media: the Extensions of Man. New York, Mc Graw-Hill, p. 5.

McLuhan, M. (1962). The Gutenberg Galaxy: The Making of Typographic Man. Toronto, University of Toronto Press.

Mullen, A. and Klaehn, J. (2010). "The Herman-Chomsky Propaganda Model: A Critical Approach to Analysing Mass Media Behaviour”, Sociology Compass 4(4), p. 217.

Murshed, S.M. (2002). "Perspectives on two phases of globalization”. S Mansuub (ed) Globalization, Marginalization and Development. London, New York, Routledge. p. 17.

Nava, M. (1991). “Consumerism Reconsidered, Buying and Power”, Cultural Studies, 5(2), p. 157.

Nordenstreng, K. (2013). "How the New World Order and Imperialism Challenge Media Studies", tripleC, 11(2), p. 348. 
Yirmibeşoğlu, G. (2017). Globalization and International Trade. International Journal of Social Sciences and Education Research, 3(5), 1787-1796.

Ritzer, G. (2008). The McDonaldization of Society. London. Pine Forge Press. p. 3. Rantanen, T. (2004). The media and globalization. London, Sage.

Robertson, R. and Khondker, H. (1998). "Discourses of Globalization: Preliminary Considerations”, International Sociology, 13 (1). p. 28.

Sassatelli, R. (2006). Virtue, Responsibility and Consumer Choice: Framing Critical Consumerism. In J.Brewer, \& F. Trentmann (Eds.) Consuming Cultures, Global Perspectives: Historical Trajectories, Transnational Exchanges. Oxford, Berg. pp. 219-250.

Semati, M. (Ed.). (2004). New Frontiers In International Communication Theory. Rowman \& Littlefield Publishers.

Sparks, C. (2012). "Media and Cultural Imperialism Reconsidered”, Chinese Journal of Communication, 5 (3). pp. 294-296.

Thompson, J. B. (1995). The Media and Modernity: A Social Theoryof the Media. Stanford University.

Tomlinson, J. (1991). Cultural Imperialism: a Critical Introduction. London New York, Continuum. p. 39.

Tunstall, J. (2013). Global Entertainment Media: between Cultural Imperialism and Cultural Globalization. NewYork, Routledge. p. 9.

Veblen, T. (1899). The Theory of the Leisure Class. New Jersey, Augustus Kelly, Fairfield. 